\title{
Effect of Coronatine on Stomatal Opening in Leaves of Broadbean and Italian Ryegrass
}

\author{
Yosuke Mino*, Yasuki Matsushita** and Ryutaro SaKaI***
}

Key words: coronatine, stomatal opening, Vicia faba, Lolium multiflorum.

Sakai et al. ${ }^{1,2)}$ reported that coronatine, a toxin produced by Pseudomonas syringae pv. atropurpurea, induced marked hypertrophy on potato tuber discs, accompanied by rapid disappearance of starch granules. On the other hand, Turner and Graniti ${ }^{3)}$ reported that fusicoccin, a toxin produced by Fusicoccum amygdali, had a physiological activity to enhance stomatal opening. The present work was done to elucidate whether coronatine affects stomatal opening as one of its functions.

Broadbean (Vicia faba, cv. Nintoku) and Italian ryegrass (Lolium multiflorum, cv. Giant) were grown in a green house for 20 days. The discs $(1.6 \mathrm{~cm}$ in diameter) from third leaves of broadbean and the third leaf blades (2 $\mathrm{cm}$ from the top) of Italian ryegrass were used for this experiment. These samples were placed in Petri dishes and kept in the dark for $1.5 \mathrm{hr}$ to make stomata close. The lower surface of these leaf segments were contacted with coronatine solution in a Petri dish and placed in the dark. Distilled water was used as control. After the treatments stomata were replicated on celluloid films after removal of excess water with a filter paper. Twenty five films in each experimental plot were observed under a light microscope. As shown in Fig. 1, stomatal aperture of broadbean was determined by subtracting B from A (A-B),

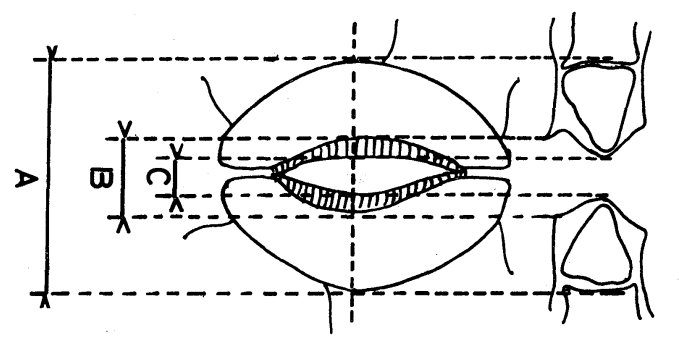

Fig. 1. Parameters for stomatal aperture. The width A-B was measured for broadbean and the width $\mathrm{C}$ for Italian ryegrass.

\footnotetext{
* Obihiro University of Agriculture and Veterinary Medicine, Inada-cho, Obihiro 080, Japan 帯 広畜産大学

** Tokachi Regional Crop Seed Center, Nippon Regional Crop Seed Association, Makubetsu 089, Japan 日本特産農作物種苗協会, 十勝特産種苗センター

*** Faculty of Agriculture, University of Hokkaido, Kitaku, Sapporo 060, Japan 北海道大学農学部 1) Sakai, K., Nishiyama, K., Ichihara, A., Shiraishi, K. and Sakamura, S. (1979). The relation between bacterial toxic action and plant growth regulator, in Recognition and Specificity in Plant Host-Parasite Interactions ( Daly, J. M. and Uritani, I. eds.) Japan Scientific Societies Press and University Park Press, pp. 165-178. 2) Sakai, R., Mino, Y., Takachi, M. and Enoki, S. (1979). Ann. Phytopath. Soc. Japan $45: 596-602.3$ ) Turner, N., C. and Graniti, A. (1969). Nature $223: 1070-$ 1071.
} 


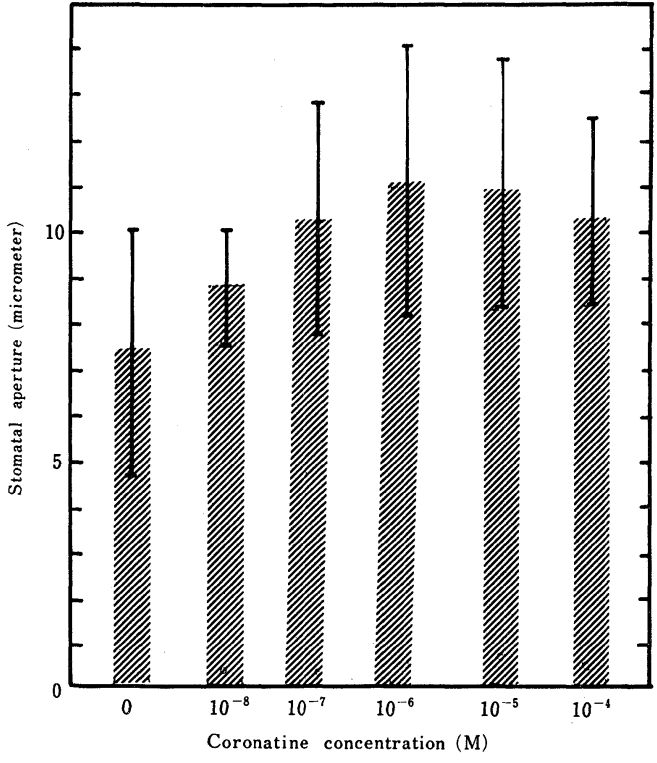

Fig. 2. Effect of coronatine concentrations on stomatal aperture of broadbean. Stomatal aperture was expressed as the width A-B (cf. Fig. 1).

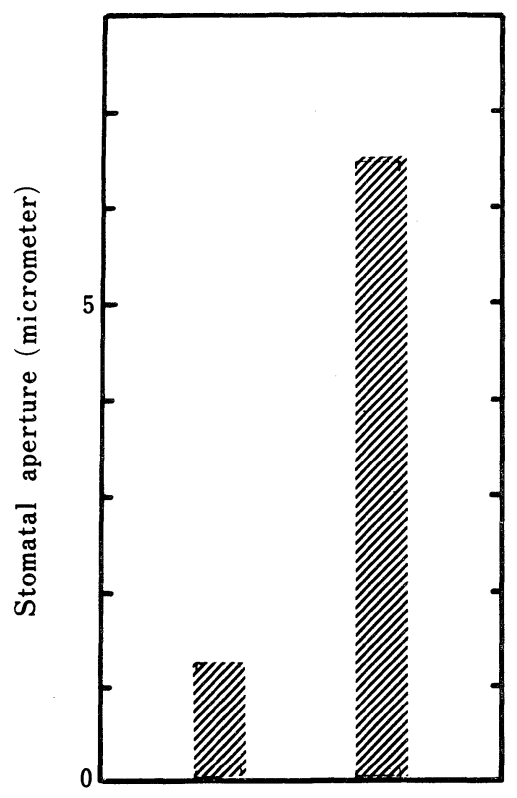

Control Coronatine

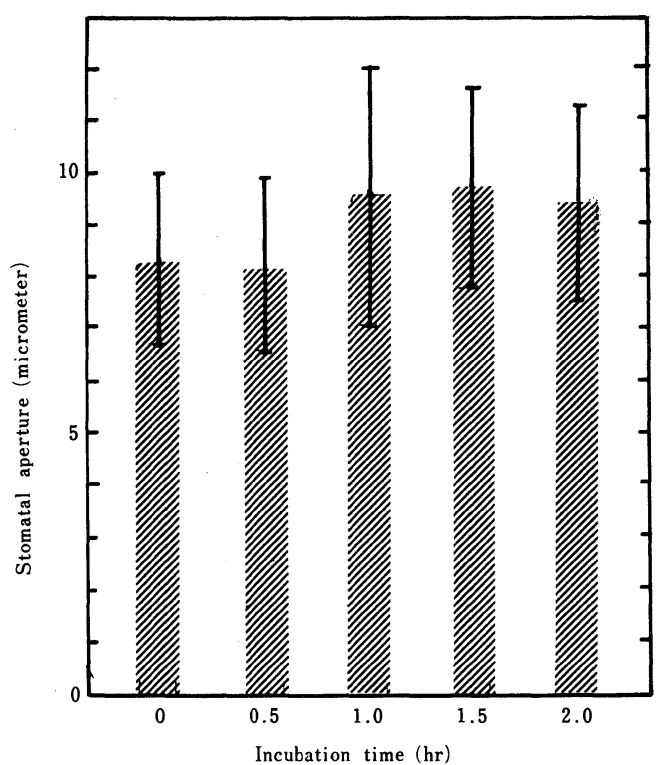

Fig. 3. Time course of coronatine treatment on stomatal aperture of broadbean. Leaves were incubated with $10^{-6} \mathrm{M}$ coronatine solution at $24 \mathrm{C}$. Stomatal aperture was expressed as the width $\mathrm{A}-\mathrm{B}$ (cf. Fig. 1).
Fig. 4. Effect of coronatine on stomatal aperture of Italian ryegrass. Leaves were treated with $10^{-6} \mathrm{M}$ coronatine solution for $1.5 \mathrm{hr}$ at $24 \mathrm{C}$. Stomatal aperture was determined as the width C (cf. Fig. 1). 
because the width $\mathrm{C}$ was not replicated clearly due to the stomatal structure with a deep hollow. On the other hand, stomatal aperture of Italian ryegrass was determined as the width $\mathrm{C}$.

Effects of concentration and treatment time. As shown in Fig. 2, stomatal aperture of broadbean was increased with increasing concentrations of coronatine until maximum was attained at $10^{-6} \mathrm{M}$. Its effect was somewhat lessened at the concentrations higher than $10^{-6} \mathrm{M}$. As shown in Fig. 3, stomatal opening was initiated $1 \mathrm{hr}$ after treatment with $10^{-6} \mathrm{M}$ coronatine.

Effect of coronatine on Italian ryegrass. As shown in Fig. 4, stomatal aperture was increased markedly by treatment with $10^{-6} \mathrm{M}$ coronatine.

Coronatine was shown to enhance stomatal opening of broad bean and Italian ryegrass in this study. Turner and Graniti ${ }^{3)}$ reported that absorption of potassium ions into guard cells was increased by fusicoccin, resulting in stomatal opening. In the light of the activation of membrane bound ATPase by coronatine ${ }^{4}$, stomatal opening by coronatine may be exerted through the same mechanism as that found with fusicoccin ${ }^{3)}$. Sakai et al. ${ }^{2}$ reported that starch granules in potato tuber discs were decomposed actively after coronatine treatment, leading to the increase in osmotic pressure in the cells. There is therefore a possibility that the increase in osmotic pressure in the guard cells caused by decomposition of starch granules is partly responsible for stomatal opening. These problems will be clarified by further experiments.

We are grateful to Mrs. Y. Yokoyama for her kind assistance.

\section{和 文 摘 要}

美濃羊輔・松下恭樹・酒井隆太郎：インゲンおよびイタリアンライグラス葉上の気孔の開口におよぼすコロ ナチンの影響

ソラマメおよびイタリアンライグラスの葉を用いて, 気孔の開口におよぼすコロナチンの影響を調べた。ソ ラマメの気孔の開度はコロナチンの濃度が高まるにつれ増大し, $10^{-6} \mathrm{M}$ で最大に達した。またコロナチンに よる気孔の開口は, 処理 1 時間後に認められた。イタリアンライグラスの場合にも, コロナチン処理により著 しい気孔の開口が認められた。

(Received August 7, 1986)

4) Sakai, R., Akima, M., Mino, Y. and Emami-Saravi, R. (1984). Ann. Phytopath. Soc. Japan 50: 653-655. 